\title{
PENGUASAAN NEGARA ATAS MIGAS SEBAGAI WUJUD KEDAULATAN ATAS SUMBERDAYA ALAM DALAM PERSPEKTIF HUKUM INTERNASIONAL KONTEMPORER
}

\author{
STATE CONTROL OVER OIL AND GAS AS SOVEREIGNTY OF \\ NATURAL RESOURCES IN PERSPECTIVE INTERNATIONAL LAW \\ CONTEMPORARY
}

\author{
A n s h a r \\ Fakultas Hukum Universitas Khairun Ternate \\ Email: ansharnatsir@gmail.com
}

Naskah diterima : 10/06/2017; revisi : 25/08/2017; disetujui : 28/08/2017

\begin{abstract}
Permanent sovereignty over natural resources includes the richness of oil and natural gas secured as one form of sovereignty owned by every nation. It is set out in UN General Assembly Resolutions and other international legal instruments. The question of sovereignty which includes the aspects of natural resource management is a crucial aspect that will be faced by every country including Indonesia in the increasingly competitive global arena. In the principle of international law sovereignty, there are three sovereign aspects that can be divided into: external sovereignty, internal sovereignty, and territorial sovereignty. Based on the analysis of the three aspects of sovereignty and then connected with the mandate of the constitution in Article 33 paragraph (3) of the 1945 Constitution of the Republic of Indonesia, Indonesia as a country that has oil and gas wealth has not been able to optimally to show its existence as a sovereign country and have full control over natural resources management, especially oil and gas.
\end{abstract}

Keywords: State Control - Sovereignty Over Natural Resources - Oil And Gas

Abstrak

Kedaulatan permanen atas sumber daya alam termasuk di dalamnya kekayaan minyak dan gas bumi (migas) dijamin sebagai salah satu bentuk kedaulatan yang dimiliki oleh setiap bangsa. Hal itu diatur dalam Resolusi Majelis Umum PBB dan berbagai instrumen hukum internasional lainnya. Persoalan kedaulatan yang termasuk di dalamnya adalah aspek pengelolaan sumber daya alam merupakan aspek krusial yang akan di hadapi oleh setiap negara termasuk Indonesia di dalam percaturan global yang semakin kompetitif. Dalam prinsip kedaulatan hukum internasional dikenal adanya tiga aspek kedaulatan yang dapat dibagi atas: kedaulatan eksternal, kedaulatan internal, dan kedaulatan teritorial. Berdasarkan analisis dari ketiga aspek kedaulatan tersebut dan kemudian disandingkan dengan amanah konstitusi pada Pasal 33 ayat (3) UUD Tahun 1945, Indonesia sebagai negara yang memiliki kekayaan migas belum mampu secara optimal untuk menunjukkan eksistensinya sebagai negara yang berdaulat dan memiliki penguasaan penuh terhadap pengelolaan sumber daya alam, khususnya migas.

Kata Kunci: Penguasaan Negara - Kedaulatan Sumber daya Alam - Minyak dan Gas Bumi

\section{PENDAHULUAN}

Kedaulatan masih menjadi diskursus yang menarik dalam menelaah kajian hukum internasional kontemporer. Terdapat berbagai pendekatan, beragam kategorisasi dan berbagai variasi tentang penggunaan makna dan konsepsi kedaulatan. Kedaulatan dapat merujuk pada kedaulatan domestik, kedaulatan interdependensi, kedaulatan 
hukum internasional, dan kedaulatan negara yang absolut. Kedaulatan sebagai konsep yang menunjuk pada kekuasaan yang utama dan tertinggi berdasarkan sudut pandang dari berbagai unsur-unsur kedaulatan, seperti: kedaulatan hukum atau kedaulatan politik; kedaulatan internal atau kedaulatan eksternal; kedaulatan yang tunggal atau kedaulatan yang dapat dibagi; dan kedaulatan pemerintah atau rakyat. ${ }^{1}$

Persoalan kedaulatan yang termasuk di dalamnya adalah aspek pengelolaan sumberdaya alam merupakan aspek krusial yang akan di hadapi oleh setiap negara termasuk Indonesia di dalam percaturan global yang semakin kompetitif. Hal tersebut tidak lain karena sumberdaya alam, khususnya minyak dan gas bumi (selanjutnya disebut: migas) yang dimiliki Indonesia sangatlah melimpah. Pengelolaan migas hingga saat ini masih memainkan peranan yang sangat penting untuk menunjang kesinambungan pembangunan Indonesia, baik sebagai salah satu andalan utama penghasil devisa, maupun sebagai pemasok kebutuhan energi dalam negeri yang berpengaruh pada ekonomi nasional. Atas dasar pengaruh tersebut, kekayaan migas yang dimiliki Indonesia dapat dinyatakan sebagai aspek terpenting dari potensi bangsa.

Sejalan dengan hal itu, George Anderson menyebutkan bahwa "natural resources are important to the politics and economics of many countries. Of all resources, oil and gas stand apart in terms of their breadth and depth of impact". ${ }^{2}$ Bagaimanapun juga migas dipandang sebagai sumberdaya

${ }^{1}$ Jens Bartelson, 2006, “The Concept of Sovereignty Revisited", 17 European Journal of International Law Vol. 17. No. 2, Oxford: Oxford University Press, hlm. 463. Lihat pula: Dan Sarooshi, 2004, "The Essentially Contested Nature of the Concept of Sovereignty: Implications For The Exercise by International Organizations of Delegated Powers of Government", 25 Michigan Journal of International Law, Summer 2004: Symposium: Diversity or Cacophony?: New Sources of Norms in International Law. Michigan: University of Michigan, hlm. 1108.

${ }^{2}$ George Anderson (Ed.), 2012, Oil and Gas in Federal Systems, Canada: Oxford University Press, hlm. 1. alam strategis yang dimiliki Indonesia. Migas dinilai strategis bukan hanya karena sumber energi yang paling utama, tetapi juga merupakan sektor sumber kekayaan alam andalan penghasil devisa. Oleh karena sejatinya kekayaan sumber daya alam adalah komponen keberhasilan pembangunan ekonomi suatu bangsa. Hal ini pula sejalan dengan pendapat bahwa "the real option value in the natural resources sector is of significant economic magnitude". ${ }^{3}$

Oleh karena itu, peran negara sebagai subjek hukum internasional dalam menguasai semua sektor pengelolaan migas adalah menjadi sangat penting untuk menjaga eksistensi suatu negara akan kedaulatan yang dimilikinya untuk mengelola sendiri kekayaan alam tanpa intervesi dan campur tangan dari pihak lain seperti bentuk eksploitasi perusahaan migas raksasa multinasional (multinational corporations) terhadap berbagai sumberdaya alam dengan dalih kerjasama bisnis internasional yang terjadi di berbagai belahan dunia.

Untuk mengantisipasi hal tersebut, rezim hukum internasional telah mengakui adanya hak yang dimiliki oleh setiap negara dan bangsa dalam hal pengelolaan sumberdaya alam dalam bentuk kedaulatan secara penuh dan utuh. Disebutkan dalam beberapa dokumen internasional dalam bentuk Resolusi Majelis Umum Perserikatan Bangsa-Bangsa (PBB) mengenai penguasaan permanen atas kekayaan sumberdaya alam untuk dipergunakan dan dimanfaatkan secara bebas oleh negara bersangkutan. Salah satunya terdapat dalam Resolusi Majelis Umum PBB Nomor 1803 Tahun 1962 yang menegaskan bahwa migas sebagai energi fosil adalah sumber daya alam nasional suatu bangsa yang dimiliki atas

3 Adi Libson, 2015, "Is the Deadweight Actually Dead? Real Option Value and Taxation of Oil and Gas", Volume 45 Issue 3 Article 3, Seton Hall Law Review, New Jersey: Seton Hall University School of Law, hlm. 843. 
A $\mathbf{n} \mathbf{s}$ h a r|Penguasaan Negara Atas Migas Sebagai Wujud Kedaulatan Atas Sumberdaya Alam Dalam....

dasar kedaulatan permanen atas kekayaan sumberdaya alamnya. ${ }^{4}$

Sebagaimana Antony Anghie menyebutkan bahwa: "The formulation of the doctrine of permanent sovereignty over natural resources was one of the principal mechanisms by which the new states hoped to regain control over their own resources and, in this way, promote development. ${ }^{5}$ Perumusan doktrin penguasaan permanen atas kekayaan sumberdaya alam berdasarkan hukum internasional merupakan hal yang sangat penting bagi setiap negara untuk mendapatkan kuasa kontrol atas kekayaan sumberdaya alam mereka sendiri. Oleh karena itu, pengelolaannya harus sesuai dengan kepentingan pembangunan nasional dari negara yang bersangkutan.

Begitu pula di beberapa instrumen hak asasi manusia internasional dalam wujud Deklarasi Umum Hak Asasi Manusia dan 2 (dua) kovenan hak asasi manusia yang menegaskan adanya prinsip hak penentuan nasib sendiri (The Right of Self-Determination) dari setiap negara akan pengelolaan sumber daya alam secara mandiri tanpa ada campur tangan dari pihak atau negara lain. Berkaitan dengan hal tersebut pula, Antony Anghie menyatakan bahwa: ${ }^{6}$ "Indeed, the idea of permanent sovereignty over natural resources was closely tied to the concept of selfdetermination, which in itself suggests the close links between political sovereignty and economic sovereignty".

Atas dasar pemikiran tersebut di atas, maka penguasaan negara atas kekayaan migas dalam bentuk pengelolaan yang mandiri dan absolut merupakan identitas yang tak dapat dipisahkan dengan persoalan kedaulatan suatu negara, terlebih lagi rezim

${ }^{4}$ Resolusi Majelis Umum PBB Nomor 1803 tahun 1962 tentang Permanent Sovereignity Over Natural Resources

${ }^{5}$ Antony Anghie, 2007, Imperialism, Sovereignty and the Making of International Law, Cambridge: Cambridge University Press, hlm. 211.

${ }^{6}$ Antony Anghie, Ibid. hukum internasional telah mengakui adanya kedaulatan penuh akan pengelolaan sumberdaya alam yang dimiliki oleh setiap bangsa dan negara.

Penelitian ini merupakan penilitian normatif, yang menggunakan pendekatan perundang-undangan dan pendekatan konseptual. Statute approach adalah pendekatan yang beranjak dari peraturan perundang-undangan dimana dalam penelitian ini mencakup konvensi-konvensi internasional ${ }^{7}$ serta undang-undang nasional yang berkaitan dengan permasalahan yang dihadapi. Conceptual approach adalah pendekatan yang beranjak pada pandangan-pandangan dan doktrin-doktrin. Dengan mempelajari pandangan-pandangan dan doktrindoktrin peneliti akan menemukan ide-ide yang melahirkan pengertian-pengertian, konsep-konsep dan asas-asas hukum yang relevan dengan isu yang di hadapi. Pemahaman atas pandangan-pandangan dan doktrin-doktrin tersebut merupakan sandaran bagi peneliti dalam membangun suatu argumentasi hukum guna memecahkan permasalahan yang dihadapi. ${ }^{8}$

\section{PEMBAHASAN}

\section{Prinsip Sovereignty Over Natural Re- sources (Kedaulatan atas Sumberdaya Alam) Berdasarkan Hukum Internasi- onal}

Migas merupakan jenis sumberdaya alam yang bernilai strategis yang dikuasai oleh negara serta merupakan komoditas vital yang menguasai hajat hidup orang banyak dan mempunyai peranan penting dalam perekonomian setiap bangsa dan negara. Dalam perspektif hukum internasional, kajian intens tentang sumberdaya alam awalnya bukan merupakan suatu objek studi untuk dianalisis dalam bidang hukum

\footnotetext{
Erlies Septiana. Nurbani, Perkembangan Teknologi Senjata dan Prinsip Proporsionalitas, Jurnal Ius Kajian Hukum dan Keadilan, Volume 5 Nomor 12017 hlm 1329.

${ }^{8}$ Ibid.
} 
internasional. Hanya saja karena kajian mengenai konsep kedaulatan permanen sumberdaya alam yang terus berkembang menjadikan kajian hukum sumberdaya alam menjadi satu dari sekian cabang bahasan dalam hukum internasional.

Hal tersebut searah dengan penjelasan Nico Schrijver bahwa: ${ }^{9}$

"Permanent sovereignty over natural resources is one of the more controversial new principles of international law that have evolved since world war two. During this period the decolonization process has taken place and newly independent states have sought to develop new principles and rules of international law in order to assert and strengthen their position in international relations and to promote their social and economic development".

Pandangan lain dari Ricardo Pereira menyebutkan bahwa: ${ }^{10}$ "The history of international law noted that before 1945, the natural resources is not an object of study that systematically studied in international law, but the development of the concept of sovereignty permanently to the natural resources, and the development of the law of the sea have made the birth of the law of natural resources as a new branch of international law." Lanjut menurut Ricardo Pereira bahwa:" "After 1945, the future of international law in the field of natural resources further the subject of discussion in various forums and influencing the policy makers and lawmakers, mainly deals with the issue of environmental damage threat caused by the exploration and exploitation of natural resources".

Bila membahas mengenai dasar pijakan yang menjadi landasan yuridis dalam

\footnotetext{
${ }^{9}$ Nico Schrijver, 1997, Sovereignty Over Natural Resources: Balancing Rights and Duties, Cambridge: Cambridge University Press, hlm. 1.

${ }^{10}$ Imam Mulyana, 2016, "The Development of International Law in the Field of Renewable Energy", Volume 2 Issue 1, April 2016, Hasanuddin Law Review, Makassar: Faculty of Law Hasanuddin University, hlm. 41.

${ }^{11}$ Imam Mulyana, Ibid., hlm. 41.
}

bingkai hukum internasional dalam kaitannya dengan pengelolaan sumber daya alam khususnya migas, tidak akan lepas dari berbagai instrumen hukum internasional yang mengatur prinsip kedaulatan negara atas hak menguasai sumberdaya alam. Prinsip kedaulatan atau hak menguasai negara atas sumberdaya alam (Sovereignty over Natural Resources) bukanlah sesuatu yang baru dan bahkan telah diakui sepenuhnya oleh hukum internasional sebagaimana dapat dijumpai dalam pelbagai dokumen resmi, diantaranya:

1. Resolusi Majelis Umum Perserikatan Bangsa-Bangsa (PBB) 626 (VII) tanggal 21 Desember 1952 tentang penentuan nasib sendiridibidang ekonomi (economic self-determination). Dalam resolusi tersebut ditegaskan mengenai hak setiap negara untuk memanfaatkan dan mengeksploitasi secara bebas kekayaan dan sumber daya alamnya, kemanapun yang dikehendaki untuk kemajuannya dan pengembangan ekonomi. ${ }^{12}$

2. Resolusi Majelis Umum Perserikatan Bangsa-Bangsa (PBB) 1803 (XVII) tanggal 14 Desember 1962, Resolusi 2158 (XXI) tanggal 25 November 1966, dan Resolusi 3016 (XXVIII) tanggal 18 Desember 1972. Resolusi ini memperluas ruang lingkup prinsip hak penguasaan permanen (permanent sovereignty) atas kekayaan alam di dasar laut dan tanah di bawahnya yang masih berada dalam yurisdiksi nasional suatu negara. ${ }^{13}$

Resolusi 1803 (XVII) juga mengedepankan kepentingan pembangunan nasional dan kesejahteraan rakyat negara bersangkutan dan menekankan bahwa perjanjian-perjanjian ekonomi termasuk investasi adalah untuk pembangunan

${ }^{12}$ A. Madjedi Hasan, 2009, Kontrak Minyak dan Gas Bumi Berasas Keadilan dan Kepastian Hukum, Jakarta: Fikahati Aneskam, hlm. 35.

${ }^{13}$ Huala Adolf, 2011, Aspek-Aspek Negara dalam Hukum Internasional, Jakarta: PT. Raja Grafindo Persada, hlm. 53-54. 
A n s h a r|Penguasaan Negara Atas Migas Sebagai Wujud Kedaulatan Atas Sumberdaya Alam Dalam....

nasional yang independen dan didasarkan pada pengakuan setiap negara atas hak menguasaikekayaan dan sumber daya alam.

Dalam resolusi 1803 tahun 1962 tentang hak menguasai tetap atas kekayaan alam, dinyatakan bahwa di setiap negara hak menguasai penuh atas kekayaan alamnya dan seluruh kegiatan ekonomi. Eksplorasi, pengembangan dan pemanfaatan dari sumber daya tersebut besertamodalasingyangdiperlukanuntuk maksud tersebut harus sesuai dengan aturandankondisidimanamasyarakatdan bangsa yang bersangkutan memandang perlu adanya otorisasi, pembatasan atau larangan terhadap kegiatan tersebut. ${ }^{14}$

Resolusi 1803 kemudian telah dijadikandasarhukumbaginegara-negara berkembang untuk meminta perbaikan atas persyaratan dan kondisi dari perjanjian-perjanjian konsesi, sedangkan beberapa resolusi lain yang tidak mengikat merupakan dasar politik yang dapat dipergunakan untuk mendorong perubahan. Resolusi-resolusi tersebut mengakui adanya hak negara untuk melakukannasionalisasiataskepemilikan asing, yang mengakibatkan meningkatnya ketidakpastian dan resiko kerugian bagi perusahaan-perusahaan asing, sehingga meningkatkan posisi tawar menawar dari negara-negara tuan rumah. ${ }^{15}$

Resolusi 2158 (XXI) merupakan upaya yang kali pertama dalam hal menghubungkan hak menguasai negara atas kekayaan alam dengan adanya berbagai tuntutan dari negara-negara berkembanguntukmemperolehporsiyang lebihbesar dan menguntungkan dalam hal

${ }^{14}$ UN General Assembly Resolution 1803 (XVII), 14 Desember 1962, Permanent Sovereignty Over Natural Resources. Resolusi 1803 ini diterima oleh Sidang Umum PBB dengan pemungutan suara dengan 87 menyetujui dan 2 menolak. Diantara negara-negara yang menyetujui adalah Amerika Serikat dan beberapa negara barat, sehingga Resolusi 1803 ini dapat dikatakan mengikat.

${ }^{15}$ A. Madjedi Hasan, Op. Cit., hlm. 36. pengolahan, pemasaran dan distribusi kekayaan alam.

3. Resolusi Majelis Umum Perserikatan Bangsa-Bangsa (PBB) 3201 (SVI) Tanggal 1 Mei 1974 tentang Deklarasi Pembentukan Tata Ekonomi Internasional Baru dan Resolusi 3281 (XXIX) Tanggal 12 Desember 1974 tentang Program Hak-hak Ekonomi dan Kewajiban Negara (Charter of Economic Rights and Duties of States), yang menegaskan kembali mengenai hak menguasai oleh negara untuk mengawasi kekayaan alamnya dalam upaya meningkatkan pertumbuhan ekonomi.

Resolusi 3201 menegaskan bahwa tata ekonomi internasional baru seharusnya didasarkan pada antara lain hak menguasai dari negara secara penuh dan untuk mengamankan sumber daya alam ini masing-masing negara berhak mengendalikan dan eksploitasinya, dimana termasuk pula melakukan nasionalisasi atau mengalihkan kepemilikan kepada negaranya sendiri.

Pada Pasal 1 Bab II Resolusi 3281 menegaskan bahwa setiap negara mempunyai kedaulatan dan inalienable right (hak yang tidak dapat diserahkan atau dialihkan tanpa persetujuan yang mempunyai hak) untuk memilih sistem ekonomi maupun sistem politik, sosial dan budaya berdasarkan kehendak rakyatnya, tanpa intervensi dari luar, pemaksaan atau ancaman dalam segala bentuk. Berikutnya pada Pasal 2 Bab II menegaskanbahwasetiapnegaramemiliki hak dan bebas melaksanakan haknya, termasuk memiliki, menggunakan dan melepaskan kekayaan, sumber daya dan kegiatan ekonominya. ${ }^{16}$

4. International Covenant on Economic, Social and Cultural Rights (ICESR) Pasal 1 dan International Covenant on

${ }^{16}$ A. Madjedi Hasan, Ibid., hlm. 37. 
Civil Political Rights (ICCPR) Pasal 1 Tanggal 16 Desember 1966. Perjanjian internasional ini menegaskan hak suatu negara untuk memanfaatkan secarabebas kekayaan alamnya. ICESR dan ICCPR yang merupakan bagian dari Universal Declaration of Human Rights Tahun 1948 adalah perjanjian internasional yang dihasilkan dari Majelis Umum PBB dan mulai berlaku 3 Januari 1976. Perjanjian iniberisi kesepakatan untuk bekerja sama dalam memberikan hak-hak ekonomi, sosial dan budaya kepada setiap individu dan/atau bangsa-bangsa.

5. Declaration on the Human Environment Tahun 1972 di Stockholm. Dalam Pasal 11 dan 12 ditegaskan bahwa negara memiliki hak berdaulat untuk memanfaatkan sumber daya alamnya sesuai dengan kebijakan pemeliharaan lingkungannya masing-masing. Dalam pemanfaatan sumber daya alam tersebut, negara bertanggung jawab atas kegiatankegiatan yang merugikan lingkungan, baik di wilayahnya sendiri, maupun di wilayah negara lain (Pasal 12 dan 11). Deklarasi Stockholm ini juga menegaskan diperlukannya perencanaan dan pengelolaan yang baik untuk menyelamatkan sumber daya alam untuk kemanfaatan generasi di masa sekarang dan yang akan datang.

\section{Penguasaan Negara atas Kedaulatan Pengelolaan Migas di Indonesia}

Kedaulatan merupakan konsep yang diakui dan menjadi dasar bekerjanya sistem hukum internasional. Ajaran fundamental mengenai kedaulatan adalah bahwa kedaulatan merupakan kekuasaan absolut atas suatu wilayah tertentu. Menurut Jenik Radon, ${ }^{17}$ kekuasaan absolut

${ }^{17}$ Jenik Radon, 2004, "Sovereignty: A Political Emotion, Not A Concept", Volume 40 Issue 195, Stanford Journal of International Law. Commemorative Issue: Balance of Power: Redefining Sovereignty in Contemporary International Law Commemorative Introduction, Summer 2004, Stanford: University of Stanford, hlm. 195. atas wilayah tersebut menjadi dasar bagi pembentuk negara sehingga pemahaman ini sangat membantu dalam mencermati dan mengevaluasi kedudukan suatu negara dalam konteks hubungan internasional yang sangat dinamis.

Konsep kedaulatan masih menjadi tema yang sangat penting dalam hal membahas hubungan internasional antar bangsabangsa dan khususnya bagi perkembangan kajian hukum internasional. ${ }^{18}$ Secara nyata, kedaulatan yang merupakan prinsip dasar dalam hubungan internasional telah bertahan selama beberapa abad dan menjadikan kedaulatan menarik untuk dikaji dari sisi makna dan praktiknya. ${ }^{19}$ Gagasan mengenai kedaulatan dalam perspektif hukum internasional telah mengalami berbagai bentuk pergeseran konsep yang diakibatkan adanya beberapa faktor. Salah satunya ialah tren perkembangan globalisasi berupa saling bergantungnya suatu negara dengan negara lain dan terjalinnya intensitas kerjasama antar negara. $^{20}$

Sesuai konsep hukum internasional, secara umum kedaulatan memiliki tiga aspek utama yaitu: ${ }^{21}$

- Aspek eksternal kedaulatan; hak bagi setiap negara untuk secara bebas menentukan hubungannya dengan berbagai negara atau kelompokkelompoklaintanpakekangan,tekanan atau pengawasan dari negara lain.

\footnotetext{
${ }^{18}$ John H. Jackson, 2006, Sovereignty, the WTO and Changing Fundamentals of International Law, Cambridge: Cambrdige University Press, hlm. 57.

${ }^{19}$ Matthew S. Weinert, 2007, Democratic Sovereignty: Authority, Legitimacy, and State in a Globalizing Age, New York: University College London Press, hlm. 194.

20 Magdalena Petronella Ferreiria-Snyman, 2009, "The Erosion of State Sovereignity in Public International Law: Towards A World Law?", Doctor Legum in Public International Law in the Faculty of Law at the University of Johannesburg, hlm. 32.

21 Maskun, 2014, "Interaksi Kejahatan Siber dan Kejahatan Agresi dalam Hukum Internasional Kontemporer", Disertasi Ilmu Hukum pada Universitas Hasanuddin Makassar, hlm. 85. Lihat juga: Magdalena Petronella Ferreiria-Snyman, Op.Cit., hlm. 35.
} 
A n s h a r|Penguasaan Negara Atas Migas Sebagai Wujud Kedaulatan Atas Sumberdaya Alam Dalam....

- Aspek internal kedaulatan; hak atau wewenang eksklusif suatu negara untuk menentukan bentuk lembaga-lembaganya, cara kerja lembaga-lembaga tersebut dan hak untuk membuat undang-undang yang diinginkannya serta tindakantindakan untuk mematuhinya.

- Aspekteritorialkedaulatanyangberarti kekuasaan penuh dan eksklusif yang dimiliki oleh negara atas individuindividu dan benda-benda yang terdapat di wilayah tersebut.

Berdasarkan tiga aspek utama kedaulatan sesuai konsep hukum internasional di atas, maka dalam membahas topik penguasaan negara atas pengelolaan migas dalam kerangka konsep kedaulatan hukum internasional pun dapat dibagi atas tiga bagian, yaitu kedaulatan eksternal; kedaulatan internal; dan kedaulatan teritorial, sebagaimana dapat diuraikan satu demi satu seperti penjelasan di bawah ini:

\section{Kedaulatan Eksternal Penguasaan Negara atas Migas}

Penguasaan negara atas migas dalam kerangka kedaulatan eksternal dapat diartikan sebagai kekuasaan tertinggi dalam wujud hak dan kewenangan eksklusif dari suatu negara di bidang pengelolaan migas untuk secara bebas menentukan hubungan internasionalnya dengan berbagai negara/ pihak lain tanpa ada halangan/ intervensi.

Hasil pengelolaan migas di Indonesia menjadi bagian terpenting dalam proses pembangunan di Indonesia. Penerimaan migas mencapai $30 \%$ dari total penerimaan pemerintah. Dengan alasan inilah migas dikatakan sebagai industri strategis dan memainkan peran penting dalam pembangunan. Terdapat berbagai sistem pengelolaan migas yang pernah berlaku di Indonesia. Hal ini menunjukkan kewenangan eksklusif yang dimiliki Indonesia sebagai negara yang memiliki kedaulatan secara eksternal untuk menentukan sendiri bentuk hubungan internasionalnya dengan berbagai pihak, khususnya perusahaan migas asing sebagai investor dan kontraktor dalam industri migas nasional. Di antara sistem pengelolaan migas tersebut, di antaranya adalah:

- Sistem Konsesi: kontraktor memiliki kekuasaan penuh atas migas, di mana yang ditambang dan wajib membayar royalti kepada negara. Sistem ini sudah tidak ada lagi sejak 1961.

- Sistem Kontrak Karya: merupakan kontrak dalam bentuk profit sharing di mana manajemen ada di kontraktor dan sudah tidak ada lagi sejak 1983.

- Sistem Kontrak Bagi Hasil atau Production Sharing Contract.

- Technical Assistance Contract (produksi yang dibagi hanya diperoleh dari pertambangan produksi setelah secondary recovery). Pembagian migas dari total produksi.

- Sistem Joint Operating Body. Kontrak ini sama persis seperti sistem kontrak bagi hasil namun pemerintah ikut serta dalam permodalan sehingga komposisi menjadi $50 \%: 50 \%$.

Namun sepanjang sejarah pengusahaan minyak di Indonesia, hanya terdapat tiga model kontrak kerjasama antara pemerintah dengan investor/ kontraktor, yaitu: sistem konsesi, sistem kontrak karya, dan sistem kontrak bagi hasil (PSC). Sistem kontrak bagi hasil merupakan sistem pengelolaan migas yang paling lama diterapkan dalam industri migas di Indonesia. Akan tetapi pada implementasinya, kontrak bagi hasil menimbulkan berbagai macam permasalahan, naik turunnya harga minyak dunia menentukan pembagian keuntungan tersebut. Hal ini belum dipengaruhi dengan kebijakan cost recovery, fee, dan pajak yang mempengaruhi penerimaan negara dengan 
sistem bagi hasil yang mengakibatkan penerimaan negara tidak mendapatkan persentase awal $85 \%$ keuntungan dari hasil produksi migas.

\section{Kedaulatan Internal Penguasaan Negara atas Migas}

Penguasaan negara atas migas dalam kerangka kedaulatan internal dapat dimaknai sebagai kekuasaan tertinggi dalam wujud hak dan kewenangan eksklusif dari suatu negara di bidang pengelolaan migas untuk menentukan bentuk, cara kerja lembaga negaranya, hak untuk membuat peraturan tanpa ada intervensi, mendapatkan kepatuhan dan memiliki kewenangan sendiri untuk memutus persoalan yang timbul di dalam jurisdiksinya. Dalam diskusi konteks kedaulatan internal pengelolaan migas di Indonesia, dapat dimulai dari pengaturan konstitusi yang diatur dalam Pasal 33 ayat (3) Undang-Undang Dasar Tahun 1945 yang menegaskan bahwa: "Bumi, air, dan kekayaan alam yang terkandung di dalamnya dikuasai oleh negara dan dipergunakan sebesar-besar untuk kemakmuran rakyat". Atas dasar amanah konstitusi tersebut terdapat dua unsur utama dalam pengelolaan bumi, air, dan kekayaan alam (termasuk migas) di Indonesia yaitu unsur "dikuasai negara" dan "sebesar-besar kemakuran rakyat". Dua unsur tersebut menjadi ruh dari setiap pengelolaan kekayaan alam tak terkecuali migas yang dimiliki Indonesia.

Selanjutnya dalam sejarah pengaturan migas di Indonesia terdapat beberapa regulasi yang pernah dan masih berlaku. Dibagi ke beberapa fase rezim pemerintahan yaitu:

- rezim kolonial Hindia-Belanda: Indische Mijnwet 1899;

- rezim pemerintahan Orde Lama: UndangUndang Nomor 44 Tahun 1960 tentang Pertambangan Minyak dan Gas Bumi;
- rezim pemerintahan Orde Baru: UndangUndang Nomor 8 Tahun 1971 tentang Perusahaan Pertambangan Minyak dan Gas Bumi Negara (Pertamina); dan

rezim pemerintahan Era Reformasi: Undang-Undang Nomor 22 Tahun 2001 tentang Minyak dan Gas Bumi.

Dengan pernah dan sedang berlakunya pengaturan (regulasi) tentang pengelolaan migas di Indonesia, menandakan bahwa Indonesia adalah negara yang mampu mewujudkan bentuk kedaulatan internal dalam hal penguasaan negara terhadap kekayaan migas dalam wujud kewenangan eksklusif untuk membuat peraturan, dimana dalam peraturan tersebut diatur mengenai secara detail bentuk dan cara kerja dari setiap lembaga yang ditunjuk oleh negara dalam bidang pengelolaan migas. Namun begitu, dalam beberapa kajian analisis pada penelitian lain membuktikan bahwa berlakunya undangundang tersebut tetap tidak dapat lepas dari pengaruh pihak-pihak lain yang memiliki kepentingan besar atas kekayaan migas yang dimiliki Indonesia. Terlebih lagi pada analisis kritis tentang pemberlakuan Undang-Undang Nomor 22 Tahun 2001 yang kini masih berlaku, mendapat beberapa sorotan seperti sifat dari undangundang ini yang mendukung ekonomi liberal industri migas internasional hingga membatasi peran perusahaan nasional (Pertamina) untuk terlibat secara dominan dalam hal pengelolaan migas. Untuk itu dapat dikatakan bahwa penguasaan negara dalam hal pengelolaan migas pada aspek kedaulatan internal ini belum sepenuhnya dapat dioptimalkan dikarenakan masih terdapatnya bentuk intervensi dari pihak luar dalam hal mendikte bentuk peraturan di bidang pengelolaan migas.

\section{Kedaulatan Teritorial Penguasaan Negara atas Migas}

Penguasaan negara atas migas dalam kerangka kedaulatan teritorial dapat 
A $\mathbf{n} \mathbf{s}$ h a r|Penguasaan Negara Atas Migas Sebagai Wujud Kedaulatan Atas Sumberdaya Alam Dalam....

dimaknai sebagai kekuasaan penuh yang dimiliki oleh suatu negara dalam hal melaksanakan jurisdiksi (kewenangan) secara eksklusif di wilayah negaranya di bidang pengelolaan migas sehingga negara berwenang menegakkan hukum nasionalnya sendiri. Dengan konsekuensi semua pihak (termasuk actor non-state yang membidangi pengelolaan migas) yang mendiami negara tersebut harus tunduk dan patuh berdasarkan prinsip qui in territorio meo est, etiam meus subditus est (apabila seseorang berada di wilayah tertentu, ia harus tunduk pada hukum wilayah tersebut).

Persoalan kemajuan dan kemandirian bangsa atas kekayaan alam yang dimilikinya berkaitan erat dengan sejarah politik dan ekonomi masing-masing negara, terlebih dalam hal ini menyangkut sejarah kolonialisme yang kecenderungannya melakukan penghisapan atas kekayaan alam di negera-negara jajahan. Namun demikian, ketika dekolonisasi terjadi dan negara-negara mengalami kemerdekaan, hubungan asimetris antara negara-negara yang baru merdeka dengan negara-negara maju tidak begitu saja berubah. Negaranegara maju dengan kemajuan sistem bisinis internasional yang dilakukan oleh perusahaan-perusahaan raksasa multinasional (Multinational Corporations) secara efektif mampu melanjutkan polapola eksploitasi berbagai sumberdaya alam termasuk migas di berbagai belahan dunia secara efektif.

Indonesia sebagai negara yang memiliki sejarah panjang sebagai bangsa bekas terjajah pun tidak luput dari cengkraman actor non-state dalam wujud perusahaan multinasional dengan konsep ekonomi liberalismenya dalam mengeksplorasi dan mengeksploitasi kekayaan migas yang melimpah di Indonesia. Hal ini menjadi catatan penting dikarenakan Indonesia yang konon dianugerahi limpahan kekayaan migas masih saja menemui berbagai macam kendala dalam hal mewujudkan kedaulatan pengelolaan migas. Fakta di lapangan banyak ditemukan kasus kelangkaan bahan bakar minyak (BBM) yang semakin melambungkan harga komoditinya. Investasi asing di sektor migas pun yang hadir di Indonesia, dinilai kerap menyedot hasil migas ke luar negeri. Kenaikan harga BBM pada tahun 2013 mengakibatkan inflasi menjadi naik sebesar 6-7\%. Kondisi ini berimplikasi pada kenaikan harga-harga barang lainnya yang memperlemah daya beli dan taraf hidup masyarakat. Masalah tersebut makin memperpanjang deret ukur masalah pengelolaan sumberdaya alam nasional.

Migas yang melimpah menjadi salah satu sumber kekayaan yang dimiliki oleh Indonesia. Di tahun 2010, cadangan minyak bumi Indonesia yang telah terbukti berjumlah 4,23 MMSTB (million stock tank barrel). Sedangkan cadangan gas Indonesia yang telah terbukti ialah 108 TSCF (trillion standart cubic feet). ${ }^{22}$ Bila diamati dalam ruang lingkup global, cadangan minyak bumi Indonesia dapat menyumbang sekitar 0,4 persen dari seluruh cadangan minyak bumi dunia. Sedangkan cadangan gas alam Indonesia menyumbang sekitar 1,6 persen dari seluruh cadangan gas alam dunia. ${ }^{23}$

22 BP Migas, (2011), "Laporan Tahunan BP Migas 2010", hlm. 16. Diperoleh tanggal 28 Januari 2012 dari http://www.bpmigas.go.id/wp-content/uploads/2011/10/LaporanTahunanBPMIGAS2010.pdf

${ }_{23}$ Cadangan dapat diklasifikasikan menjadi cadangan terbukti dan cadangan potensial. Cadangan terbukti adalah cadangan minyak atau gas alam yang jumlahnya sudah di buktikan dengan derajat kepastian tinggi melalui analisis kuantitatif log sumur yang dapat dipercaya, serta melalui penelitian dan pengujian kandungan lapisan dan kandungan hidrokarbon dari reservoir yang sudah menghasilkan pada tingkat produksi komersil. Sementara cadangan potensial adalah cadangan minyak atau gas alam berdasarkan data geologi dan keteknikan yang jumlahnya masih harus dibuktikan dengan pengeboran serta pengujian lebih lanjut. Data diperoleh dari Beyond Petroleum, 2012,"BP Statistical Review World Energy 2011". Diperoleh tanggal 2 September 2014 dari http://www.bp.com/liveassets/bp_internet/globalbp/globalbp_uk_english/ reports_and_publications/statistical_energy_review_2011/STAGING/local_assets/pdf/statistical_review_of_world_energy_full_report_2011.pdf 
Oleh karena itu, tidak mengherankan sejak tahun 1970-an, migas menjadi komoditas ekspor terpenting Indonesia. Bahkan sebelum tahun 2006, Indonesia sempat menjadi negara pengekspor LNG (Liquified Natural Gas) terbesar di dunia selama hampir tiga dekade. ${ }^{24}$

Sumber lain dari Satuan Kerja Khusus Pelaksana Kegiatan Usaha Hulu Minyak dan Gas Bumi (SKK Migas) menyebutkan bahwa di awal tahun 2015 cadangan minyak bumi nasional saat ini tinggal 3,7 miliar barrel dari sekitar 27 miliar barel cadangan minyak yang terbukti ada (proven reserve) karena sebelumnya sudah terproduksi sekitar 22,9 miliar barrel. Diperkirakan cadangan tersebut akan bertahan sekitar 10 tahunan lagi. Meski demikian, Indonesia sebenarnya masih memiliki 43,7 miliar barel cadangan minyak, namun hal ini membutuhkan pendanaan eksplorasi dan teknologi sangat tinggi. ${ }^{25}$ Sedangkan cadangan gas alam Indonesia terhitung di awal tahun 2015 adalah sebesar 151,33 TSCF atau meningkat 1,36 persen bila dibandingkan cadangan gas alam di tahun 2014 sebesar 149,3 TSCF. $^{26}$

Indonesia sebagai negara yang memiliki cadangan migas terbesar khususnya di wilayah Asia Tenggara membuat negara ini menjadi daya tarik pemilik modal dunia. Bahkan sebelum Indonesia terbentuk sebagai negara yang berdaulat, negara ini sudah menjadi soroton pemodal asing untuk berperan dalam sektor pertambangan termasuk pertambangan migas. ${ }^{27}$ Kondisi

${ }^{24}$ Hanan Nugroho, 2011, A Mosaic Of Indonesian Energy Policy, Bogor: Press, hlm.14.

${ }^{25}$ Lihat: www.kompas.com, "Cadangan Minyak Indonesia Tinggal 3,7 Miliar Barrel”, 7 September 2015, diperoleh pada 7 Agustus 2016 dari http://bisniskeuangan.kompas.com/read/2015/09/07/073500026/Cadangan.Minyak.Indonesia.Tinggal.3.7.Miliar.Barrel

${ }^{26}$ Lihat: www.kompas.com, "Cadangan Gas Bumi Indonesia 2015 Meningkat", 16 November 2015, diperoleh pada 7 Agustus 2016 dari http://www.migas.esdm.go.id/ post $/ \mathrm{read} /$ cadangan-gas-bumi-indonesia-2015-meningkat

${ }^{27}$ M. Kholid Syeirazi, 2009, Di Bawah Bendera Asing, Liberalisasi Industri Migas di Indonesia, Jakarta: Pustaka LP3ES Indonesia, hlm. 51. ini membuat pemerintah Belanda di masa kolonial mengeluarkan Indische Mijnweet 1899 semacam undang-undang yang mengatur tentang pertambangan. Kebijakan ini memberikan izin pertambangan melalui sistem konsesi yang berlaku hingga tujuh puluh lima tahun kepada perusahaan swasta. Sejak saat itulah perusahaan multinasional mulai berperan aktif dan berpartisipasi dalam mengeksplorasi dan mengeksploitasi sektor tambang Indonesia dan menandai masuknya negara ini dalam jaringan perdagangan migas dunia.

Eksistensi perusahaan migas asing di Indonesia yang telah hadir lebih seabad lalu, membuat hegemoni atau dominasi perusahaan migas asing begitu kuat. Sekitar 85,4 persen dari 137 wilayah kerja pertambangan migas nasional dimiliki perusahaan-perusahaan asing. Perusahaan nasional hanya menguasai sekitar 14,6 persen wilayah kerja dan delapan persen diantaranya dikuasai Pertamina. ${ }^{28} \mathrm{Hal}$ ini membuat keberadaan perusahaanperusahaan migas asing di Indonesia sangat signifikan. Di bidang minyak, salah satu perusahaan migas asing yakni Chevron bahkan memproduksi 51 persen dari seluruh total produksi minyak di Indonesia. Sedangkan untuk gas alam, salah satu perusahaan migas asing yakni Total E\&P memproduksi 34 persen dari total produksi gas alam Indonesia. ${ }^{29}$

${ }^{28}$ Ibid., hlm. 108. Lima kontraktor asing yang masuk kategori super majors (ExxonMobil, Chevron, Shell, Total dan BP) menguasai cadangan migas masing-masing 70 persen minyak dan 80 persen gas dengan volume dan kapasitas produksi 68 persen minyak dan 82 persen gas. Sementara perusahaan yang masuk kategori majors (Conoco, Repsol, Unocal, Santa Fe, Gulf, Premier Oil, Lasmo, Inpex, Japex, d11) menguasai cadangan migas masing-masing 18 persen minyak dan 15 persen gas dengan volume dan kapasitas produksi 28 persen minyak dan 15 persen gas. Perusahaan-perusahaan yang masuk kategori independen menguasai cadangan migas masing-masing 12 persen minyak dan 5 persen gas dengan volume dan kapasitas produksi 4 persen minyak dan 3 persen gas.

${ }^{29}$ PricewaterhouseCooper, (2012), Oil \& Gas in Indonesia : Investment and Taxation Guide May 2012. hlm. 22. Diperoleh tanggal 3 September 2014 melalui http://www.pwc.com/id/en/publications/ assets/oil-and-gas-guide_2012.pdf 
A $\mathbf{n} \mathbf{s}$ h a r|Penguasaan Negara Atas Migas Sebagai Wujud Kedaulatan Atas Sumberdaya Alam Dalam....

Sumber lain menyebutkan bahwa perusahaan migas asing yang beroperasi di Indonesia menguasai 76 persen wilayah kerja atau hulu migas dan sisanya 24 persen barulah dikuasai oleh perusahaan nasional. Hal ini menunjukkan bahwa nilai persentase ini masih lebih kecil bila dibandingkan negara Malaysia dengan 30 persen dan Cina dengan 85 persen yang menguasai wilayah kerja migas oleh perusahaan nasional mereka sendiri. ${ }^{30}$

Hal yang dialami Indonesia seperti di atas tidak terlepas dari sejarah dan pengaruh perusahaan migas internasional yang mendominasi pengeloaan migas dunia. Disebutkan Leslie E. Grayson bahwa: ${ }^{31}$

"In 1970, about 70 per cent of the world's oil trade was handled by the oil multinationals - Exxon, Royal Dutch/Shell, Mobil, Texaco, Standart of California, Gulf, and British Petroleum. A decade later, the multinational's share has declined to about 50 per cent. Some of the trade no longer handled by the MNCs has moved to the 'spot' market in which both the multinational and national oil companies participate".

Sejalan dengan hal di atas Daniel E. Vielleville dan Baiju Simal Vasani mengemukakan pendapat bahwa: ${ }^{32}$

\section{"Many governments granted generous con- cessions in the early years to multinational oil corporations in which title to the oil in place was conveyed to the companies, the concession covered large areas, the terms of the concessions were very long (e.g., 60}

30 Lihat: www.tempo.co, "Aturan Pengelolaan Wilayah Kerja Migas Rugikan Pertamina”, 27 Mei 2015, diperoleh pada 7 Agustus 2016 dari https://m.tempo.co/read/news/2015/05/27/090669970/aturan-pengelolaan-wilayah-kerja migas-rugikan-pertamina

${ }^{31}$ Leslie E. Grayson, 1981, National Oil Companies, Norwich: John Wiley and Sons, hlm. 1.

${ }^{32}$ Daniel E. Vielleville \& Baiju Simal Vasani, 2008, "Sovereigty Over Natural Resources Versus Rights Under Investment Contracts: Which One Prevails?", Volume 5, Issue 2, April 2008, Transnational Dispute Management Journal, hlm. 1. years or more) and the royalties payable to the government were low".

Sektor pertambangan khususnya migas berbeda dengan sektor industri lainnya. Ini disebabkan karena pada sektor ini membutuhkan modal dan resiko yang sangat besar, proses eksplorasi yang cukup panjang, teknologi tinggi yang tentunya disertai dengan sumber daya manusia yang telaten di bidang tersebut. Hal ini pula yang membuat perusahaan migas dalam negeri belum banyak yang berani mengambil langkah untuk maju dan bersaing dalam industri migas. Berbeda dengan perusahaan migas asing yang telah memiliki pengalaman serta modal yang cukup banyak. Bahkan perusahaan-perusahaan multinasional ini mengklaim dapat membantu menaikkan pendapatan nasional dengan meningkatkan hasil produksi disertai peningkatan mutu sumber daya manusia dalam bentuk edukasi ke tenaga kerja Indonesia agar memiliki kompetensi dan tingkat keahlian yang sama dimiliki oleh tenaga kerja asing yang bergerak di bidang industri migas.

Berbeda dengan klaim perusahaanperusahaan migas tersebut, pada kenyataannya pun teknologi industri migas tidak tertransfer secara baik kepada Indonesia yang menyebabkan pengelolaan migas masih dikuasai oleh perusahaan migas asing. ${ }^{33}$ Hal ini membuat produksi migas dalam negeri tidak terkontrol dengan baik. Terbukti dengan keluarnya Indonesia sebagai negara anggota OPEC (Organisation of the Petroleum Exporting Countries) di

${ }^{33}$ Terlebih lagi di Indonesia, praktik pengelolaan sumber daya alam yang dilakukan perusahaan multinasional mulai mendapat sorotan serius. Hal ini dikarenakan perusahaan multinasional yang beroperasi di Indonesia dianggap telah menikmati keuntungan yang tidak seimbang jika dibandingkan dengan besaran royalti yang diberikan kepada Pemerintah Indonesia. Disamping itu, hakikat hak menguasai negara terhadap kekayaan alam di Indonesia untuk sebesar-besar kemakmuran rakyat menjadi salah satu hal yang mendasari dilakukannya gerakan nasional dalam mereposisi kedudukan Indonesia di dalam berbagai kontrak investasi asing di Indonesia. Penjelasan ini dikutip dari: Juajir Sumardi, 2012, Hukum Perusahaan Transnasional dan Franchise, Makassar: Arus Timur, hlm. 9. 
tahun 2005 (sekalipun di tahun 2015 Indonesia kembali tergabung sebagai negara anggota OPEC). Disebutkan bahwa: ${ }^{34}$

"Indonesia has been an active player ini the international oil and gas industry for more than 120 years, and was once significant international oil-exporting country and a member of the Organisation of the Petroleum Exporting Countries (OPEC). Today, Indonesia continues to be a leading exporter of pipeline and liquefied natural gas, but has experienced a fairly consistent decline in oil production since 1998, leading to the country becoming a net oil importer by 2004 ".

Indonesia yang dahulu dikenal sebagai negara pengekspor migas harus menerima kenyataaan menjadi negara pengimpor migas. Ini dikarenakan Indonesia memiliki kebutuhan akan minyak sebesar 1,3 juta bph (barel per hari) sedangkan produksi nasional negara ini hanya mampu mencapai 910.000 bph (barel per hari). Oleh karenanya untuk menutupi kekurangan pasokan dalam negeri, Indonesia harus mengimpor minyak dari negara lain. ${ }^{35}$

Harga minyak bumi yang pernah mengalami kenaikan yang sangat drastis

34 Lihat: Marc Hammerson (Consulting Editor), 2013, Oil and Gas Decommissioning: Law, Policy and Comparative Practice, London: Globe Bussines Publishing Ltd, hlm. 285.

${ }^{35}$ Ditengah kebutuhan akan minyak yang semakin meningkat, ekspor minyak dari produksi perusahaan migas asing tetap berlangsung tiap tahunnya dan di tahun 2010 ekspor minyak Indonesia berjumlah 1121 juta barel. (Data dari Kementerian Energi dan Sumber Daya Mineral, 2011, "Statistik Minyak Bumi", hlm. 8. Diperoleh tanggal 6 September 2014 melalui http://prokum.esdm.go.id/ Publikasi/Statistik/Statistik persen20Minyak persen20Bumi.pdf). Hal ini tentu kontras dengan kenyataan bahwa akses akan listrik dan bahan bakar Indonesia termasuk yang rendah di Asia. Persentase rumah tangga yang memiliki listrik hanya sekitar 60 hingga 70 persen. Sementara itu, daerah pedesaan di Indonesia yang memiliki listrik hanya sekitar 85 persen. Hal ini berarti terdapat 10.000 daerah perkampungan di Indonesia yang masih dalam kegelapan dan menunggu untuk masuknya listrik. Pemadaman secara bergilir pun masih di rasakan oleh seluruh masyarakat Indonesia. di tahun 2003 silam menjadi peringatan serius bagi negara-negara yang tengah merencanakan program keamanan energinya, termasuk pula Indonesia. Harapan akan kehadiran perusahaanperusahaan migas asing untuk dapat membantu pengelolaan migas di Indonesia ternyata tidak berjalan baik. Hadirnya perusahaan-perusahaan migas asing di negara berkembang seperti Indonesia cenderung menampakkan ketidakseimbangan kekuatan tawar menawar dalam menyatukan semua kepentingan. Termasuk pula didalamnya kepentingan nasional akan ketersediaan migas yang tentunya untuk kebutuhan seluruh rakyat.

Sejarah industri perminyakan di Indonesia mencatat bahwa ketergantungan terhadap teknologi dan permodalan terhadap pihak asing begitu dominan. Kecenderungannya berimplikasi bahwa hampir seluruh kebijakan negara di sektor pengelolaan migas mulai dari tingkat hulu hingga hilir dikooptasi oleh pihak asing. Naik turunnya harga minyak yang dirasakan oleh masyarakat Indonesia juga merupakan pengaruh dari mekanisme pasar minyak internasional. Kondisi ini dapat terjadi sebagai akibat langsung dari tingginya tingkat konsumsi masyarakat yang tidak berimbang dengan tingkat produksi dan eksploitasi minyak mentah di Indonesia yang memerlukan teknologi dan modal besar yang dinilai hanya bisa dipenuhi melalui investasi permodalan dari perusahaanperusahaan migas internasional.

Bagi negara penghasil migas seperti Indonesia, kedaulatan pengelolaan migas adalah kunci bagi suatu negara untuk dapat mencapai cita-cita mensejahterahkan rakyatnya dan membangun peradaban ekonomi yang lebih maju. Kehadiran perusahaan-perusahaan migas asing yang sangat dominan tentu sangat berpengaruh pada hadirnya kedaulatan yang utuh dalam hal pengelolaan migas dalam negeri. Hal ini 
mengidentifikasikan adanya ancaman dan krisis kedaulatan berupa intervensi pihak asing pada pengelolaan migas. Hal ini pula membuat seolah-olah negara tidak memiliki kekuatan dalam hal 'menentukan nasibnya sendiri' (right of self determination) dalam hal pengelolaan migas dalam negerinya yang diperuntukkan bagi sebesar-besar kemakmuran rakyat yang pada prinsipnya sesuai dengan landasan konstitusi dan ditunjang pula dengan prinsip dasar atau kaidah berdasarkan hukum internasional.

\section{SIMPULAN}

Penguasaan negara akan pengelolaan migas ataupun sumberdaya alam lainnya merupakan bagian dari wujud kedaulatan negara. Dalam pengaturan hukum internasional, dikenal adanya kedaulatan permanen atas sumberdaya alam (permanent sovereignty over natural resources), dimana setiap negara memiliki tiga aspek penguasaan akan kedaulatan tersebut yaitu kedaulatan eksternal, kedaulatan internal, dan kedaulatan teritorial. Kedaulatan eksternal di bidang pengelolaan migas diartikan bahwa negara dapat secara bebas menentukan hubungan internasionalnya dengan berbagai negara/ pihak lain tanpa ada halangan/ intervensi. Sedangkan kedaulatan internal dimaknai bahwa negara berhak menentukan bentuk, cara kerja lembaga negaranya, hak untuk membuat peraturan tanpa ada intervensi, mendapatkan kepatuhan dan memiliki kewenangan sendiri untuk memutus persoalan yang timbul di dalam jurisdiksinya.

Selanjutnya kedaulatan teritorial diartikan sebagai penguasaan negara atas migas sebagai bentuk kekuasaan penuh yang dimiliki oleh suatu negara dalam hal melaksanakan jurisdiksi (kewenangan) secara eksklusif di wilayah negaranya di bidang pengelolaan migas sehingga negara berwenang menegakkan hukum nasionalnya sendiri. Dari ketiga aspek kedaulatan pengelolaan migas tersebut, Indonesia sebagai negara penghasil migas belum dapat secara optimal menjalankan peran negara untuk dapat menguasai secara penuh bentuk produksi migas dalam negeri dan masih sangat bergantung pada kekuatan modal dan teknologi para perusahaan migas asing selaku investor/ kontraktor, dimana hal ini mempengaruhi masih minimnya pendapatan nasional industri migas.

\section{DAFTAR PUSTAKA}

A. Madjedi Hasan, 2009, Kontrak Minyak dan Gas Bumi Berasas Keadilan dan Kepastian Hukum, Jakarta: Fikahati Aneskam.

Adi Libson, 2015, "Is the Deadweight Actually Dead? Real Option Value and Taxation of Oil and Gas", Volume 45 Issue 3 Article 3, Seton Hall Law Review, New Jersey: Seton Hall University School of Law.

Antony Anghie, 2007, Imperialism, Sovereignty and the Making of International Law, Cambridge: Cambridge University Press, hlm. 211.

Dan Sarooshi, 2004, "The Essentially Contested Nature of the Concept of Sovereignty: Implications For The Exercise by International Organizations of Delegated Powers of Government", 25 Michigan Journal of International Law, Summer 2004: Symposium: Diversity or Cacophony?: New Sources of Norms in International Law. Michigan: University of Michigan.

Daniel E. Vielleville \& Baiju Simal Vasani, 2008, "Sovereigty Over Natural Resources Versus Rights Under Investment Contracts: Which One Prevails?", Volume 5, Issue 2, April 2008, Transnational Dispute Management Journal.

Erlies Septiana. Nurbani, Perkembangan 
Teknologi Senjata dan Prinsip Proporsionalitas, Jurnal Ius Kajian Hukum dan Keadilan, Volume 5 Nomor 12017

George Anderson (Ed.), 2012, Oil and Gas in Federal Systems, Canada: Oxford University Press.

Hanan Nugroho, 2011, A Mosaic Of Indonesian Energy Policy, Bogor: Press.

Huala Adolf, 2011, Aspek-Aspek Negara dalam Hukum Internasional, Jakarta: PT. Raja Grafindo Persada.

Imam Mulyana, 2016, "The Development of International Law in the Field of Renewable Energy", Volume 2 Issue 1, April 2016, Hasanuddin Law Review, Makassar: Faculty of Law Hasanuddin University, hlm. 41.

Jenik Radon, 2004, "Sovereignty: A Political Emotion, Not A Concept", Volume 40 Issue 195, Stanford Journal of International Law. Commemorative Issue: Balance of Power: Redefining Sovereignty in Contemporary International Law Commemorative Introduction, Summer 2004, Stanford: University of Stanford.

Jens Bartelson, 2006, "The Concept of Sovereignty Revisited", 17 European Journal of International Law Vol. 17. No. 2, Oxford: Oxford University Press.

John H. Jackson, 2006, Sovereignty, the WTO and Changing Fundamentals of International Law, Cambridge: Cambrdige University Press.

Juajir Sumardi, 2012, Hukum Perusahaan Transnasional dan Franchise, Makassar: Arus Timur.

M. Kholid Syeirazi, 2009, Di Bawah Bendera Asing, Liberalisasi Industri Migas di Indonesia, Jakarta: Pustaka LP3ES Indonesia.
Magdalena Petronella FerreiriaSnyman, 2009, "The Erosion of State Sovereignity in Public International Law: Towards A World Law?", Doctor Legum in Public International Law in the Faculty of Law at the University of Johannesburg.

Maskun, 2014, "Interaksi Kejahatan Siber dan Kejahatan Agresi dalam Hukum Internasional Kontemporer", Disertasi Ilmu Hukum pada Universitas Hasanuddin Makassar.

Marc Hammerson (Consulting Editor), 2013, Oil and Gas Decommissioning: Law, Policy and Comparative Practice, London: Globe Bussines Publishing Ltd.

Matthew S. Weinert, 2007, Democratic Sovereignty: Authority, Legitimacy, and State in a Globalizing Age, New York: University College London Press.

Nico Schrijver, 1997, Sovereignty Over Natural Resources: Balancing Rights and Duties, Cambridge: Cambridge University Press. 